\title{
According to Primary School Teachers' Views on S-STEM (Social Studies + STEM): A Phenomenological Research
}

\author{
Tuğba Selanik Ay \& Nil Duban \\ Afyon Kocatepe University, Afyonkarahisar, TURKEY \\ Department of Primary Education
}

Received: 10 September 2021 - Accepted: 9 November 2021 - Published Online: 27 November 2021

\begin{abstract}
STEM is the abbreviation of Science, Technology, Engineering and Mathematics, and S-STEM is with the addition of the Social Studies discipline. It is thought that getting the views of teachers who have made practical studies on STEM about S-STEM will shed light on both policy-makers and researchers. The aim of the research is to get the views of the primary teachers about SSTEM. This research is a phenomenological study within the scope of basic qualitative research method. Participants of this study are eight primary school teachers. Telephone interviews were used in the interview technique used in this phenomenological study. The data obtained in the research were evaluated by qualitative data analysis. Results were obtained such as the definition of STEM, STEM implementations, dimensions which integrate to STEM, suggestions on integrating social studies to STEM, values and skills which handled with STEM, suggestions for effective S-STEM implementations.
\end{abstract}

Keywords: STEM, S-STEM, Social Studies, primary school, teachers.

\section{Introduction}

Current education systems aim to provide effective teaching and learning approaches to deal with economic races, constantly growing technologies, abundance of information and other concerns of the $21^{\text {st }}$ century (Wells, 2008). One of these approaches is STEM perception. STEM (Science, Technology, Engineering and Mathematics), which is the English abbreviation of Science, Technology, Engineering and Mathematics disciplines, was created in 2001 at the National Science Foundation of America (NSF) (Chute, 2009). NSF was the first institution to call the integration of science, technology, engineering and mathematics disciplines as STEM (Sanders, 2009). Since sustainable economic growth and a brighter future target are at stake, demand for STEM has gained momentum especially in recent years (Langdon, Mckittrick, Beede, Han \& Doms, 2011). STEM education, which is an interdisciplinary field, has two main objectives. The first is to increase the number of students preparing for university to pursue a career in science, technology, engineering and mathematics, and the second is to increase the competence of all students in the basic STEM knowledge field. This aim is to develop the skills of students and employees to evaluate problems, use STEM concepts and apply creative solutions to their daily lives (Thomasion \& National Research Council, 2011: 11). Thus, students who become STEM literate individuals realize how science branches shape our material, intellectual and cultural world. In addition, these individuals, as responsible, effective and constructive citizens, find

(C) Authors. Terms and conditions of Creative Commons Attribution 4.0 International (CC BY 4.0) apply. Correspondence: Nil Duban, Afyon Kocatepe University, Education Faculty, Afyonkarahisar, TURKEY. E-mail: nily@aku.edu.tr. 
solutions to STEM related problems through the ideas of science, technology, engineering and mathematics (Bybee, 2010: 31).

Developments in science, technology and economy have changed the way people work and live. In order to keep up with this pace in today's world, individuals must have 21st century skills such as critical thinking, problem solving, teamwork, leadership, flexible thinking, adaptation, entrepreneurship, verbal-written communication, access to information, analysis and creativity (Wagner, 2008: 21-22). For this reason, different disciplines can be added to the STEM approach in order to reinforce the mentioned skills better. Approaches of STEAM with the addition of the Art discipline, E-STEM with the addition of the Entrepreneurship dimension and S-STEM with the addition of the Social Studies discipline are active in the literature. The contribution of STEM education in the context of understanding the transformative potentials of individuals to overcome social problems and structural inequalities (such as effective citizenship participation, social responsibility) is also considered important in raising effective citizens for a more democratic society. For this reason, STEM is directly related to the Social Studies course in terms of both the process and the resulting outputs (Garibay, 2015).

Social Studies, including disciplines such as history, political science, geography, and economy, are also directly related to anthropology and psychology. In the context of K-12, it can be said that hierarchically, it ranks lower among the courses in the primary school program, although it has a mission to prepare citizens to join a democratic society historically. It is also true that despite the Social Studies course aimed at ensuring democratic participation, many citizens either do not participate in civilian tasks such as national elections or global interaction, or are unaware that this is critical for the viability and continuation of a democratic state (Pryor \& Kang, 2013). In this context, the National Research Council (NRC, 2011) stated the contribution of integrating the Social Studies course to STEM in terms of gaining citizenship skills and realizing democratic participation as follows:

"One of the main goals of STEM education is to equip new generation citizens with the knowledge and skills necessary to engage in public debates about science issues and policies and make informed personal and citizenship decisions."

The National Council of Social Studies (NCSS, 2017) defines the Social Studies course as an integrated study of Social Studies and humanities to promote citizenship competence. In essence, it states that Social Studies realize the knowledge and participation regarding citizenship within the school curriculum by coordinating disciplines as anthropology, archeology, economics, geography, history, law, philosophy, political science, psychology, religion and sociology and by associating the appropriate content from humanities with mathematics and nature sciences with a systematic study. By adding one or more components of Social Studies (such as geography, history or economy) to the STEM approach, the S-STEM creates a contextual approach by linking courses to real life. Thus, by integrating the disciplines that emerge with the S-STEM approach, Social Studies are added to STEM, making the content logical, uninterrupted and effective (Awash in trash). In young children, implementations such as fairy tales and sports activities that will attract their attention can be realized during STEM studies. Literary products, fairy tales, or case studies can be given by relating them with the issues to be selected directly from students' homes or environments to address some phenomena and problems. One of the anecdotes that best demonstrated the role of the Social Studies course in the STEM integration was experienced in a STEM study as follows (Carrol \& Scott, 2017):

"While discussing with children how people can be protected from the recent floods and hurricanes in the region as part of a STEM kit, a third grade student from a primary school expressed a possible solution for protection against flood as using large rice bags to keep water away from their homes. Stating that she learned this information in Social Studies course, she emphasized that the rice specific to his 
region was used to keep water away from houses in the environment where he lived historically. He made suggestions for the use of rice as a possible flood solution."

In this context, integrating the relevant achievements of the Social Studies curriculum into STEM offers students the opportunity to examine economic, political and social problems. It helps to activate the areas of reading, writing and speaking, which can affect design decisions directly or indirectly. Students build purposeful and useful links to math skills while developing and applying these skills. Authentic learning environments provide the student with a transparent view so that they can see the whole picture (Meyrick, 2011). Inquiry-based learning that stands out in STEM and place-based learning that stands out in Social Studies courses can be expressed as supporting approaches. In this context, with the Social Studies course that can be integrated into STEM, students can be included in the inquiry process, experience the value of asking questions and joy of finding solutions, associating studies with daily life, making problems and solutions more important and meaningful (Adams, Miller, Soul \& Pegg, 2014). Maguth (2012) found as a result of his research that he thoroughly examined the integration of Social Studies into STEM based on the views of Social Studies teachers that Social Studies is a unifying and indispensable element for STEM, and in the context of many controversial decisions regarding science, technology, mathematics and engineering in STEM, the unifying aspect of Social Studies should be employed in the context of seeking the social benefit and meeting and revealing the needs, and solving problems.

Thus, teachers can transfer creativity in a traditional analytical curriculum with STEM disciplines, rather than approaching students from a narrow and one-disciplinary perspective to explain the multidisciplinary nature and complex structure of innovative thinking and scientific innovations (Manfra, 2013). In this context, elementary school programs in Turkey have a suitable structure to implement S-STEM. When the structure of the primary school curriculum is examined, key competencies and values, skills such as innovative thinking meet on a common ground, and engineering and design skills are supported by the science curriculum. The skills, values and learning areas mentioned in the primary school curriculum are emphasized in the curriculum of science and Social Studies courses as follows.

Table 1. General structure of Science and Social Studies curricula

\begin{tabular}{|l|l|l|}
\hline \multirow{4}{*}{$\begin{array}{l}\text { Learning } \\
\text { areas }\end{array}$} & Social Studies curriculum & Science curriculum \\
\cline { 2 - 3 } & Individual and Society & Living beings and life \\
\cline { 2 - 3 } & Culture and Heritage & Matter and transformation \\
\cline { 2 - 3 } & People Places and Environments & Physical events \\
\cline { 2 - 3 } & Production Distribution and Consumption & Earth and universe \\
\cline { 2 - 3 } & Science Technology and Society & \\
\cline { 2 - 3 } & Active Citizenship & \\
\cline { 2 - 3 } & Global Connections & \\
\hline
\end{tabular}

As seen in Table 1 there are seven learning areas in social studies curriculum and four learning areas in science curriculum.

Values in Science and Social Studies curricula as follows in Table 2.

Table 2. Values in the Science and Social Studies curricula

\begin{tabular}{|l|l|l|}
\hline & Social Studies curriculum & Science curriculum \\
\hline \multirow{4}{*}{ Values } & Justice & Justice \\
\cline { 2 - 3 } & Care about family unity & Friendship \\
\cline { 2 - 3 } & Independence & Honesty \\
\cline { 2 - 3 } & Peace & Self-Control \\
\cline { 2 - 3 } & Scientificness & Responsibility \\
\hline
\end{tabular}


T. Selanik Ay \& N. Duban - According to Primary School Teachers’ Views S-STEM ...

\begin{tabular}{|l|l|l|}
\hline & Diligence & Respect \\
\cline { 2 - 3 } & Solidarity & Patience \\
\cline { 2 - 3 } & Sensitivity & Love \\
\cline { 2 - 3 } & Honesty & Helpfulness \\
\hline & Aesthetic & Patriotism \\
\hline & Freedom & \\
\cline { 2 - 3 } & Equality & \\
\hline & Respect & \\
\cline { 2 - 3 } & Affection & \\
\hline & Responsibility & \\
\hline & Economy & \\
\hline & Patriotism & \\
\cline { 2 - 3 } & Helpfulness & \\
\hline
\end{tabular}

As seen in Table 2 there are 18 values in social studies curriculum and there are 10 values in science curriculum.

Skills in the Science and Social Studies curricula as follows in Table 3.

Table 3. Skills in the Science and Social Studies curricula

\begin{tabular}{|l|l|}
\hline Social Studies & Science \\
\hline Research & Scientific process skills \\
\hline Environmental literacy & Life skills \\
\hline Perceiving change and continuity & Engineering and design skills \\
\hline Digital literacy & \\
\hline Critical thinking & \\
\hline Empathy & \\
\hline Financial literacy & \\
\hline Entrepreneurship & \\
\hline Observation & \\
\hline Mapping literacy & \\
\hline Communication & \\
\hline Cooperation & \\
\hline Noticing stereotypes and prejudices & \\
\hline Decision making & \\
\hline Location analysis & \\
\hline Media literacy & \\
\hline Perceiving place & \\
\hline Self-regulatory & \\
\hline Political literacy & \\
\hline Problem solving & \\
\hline Social participation & \\
\hline Drawing table, graphic and diagram & \\
\hline Using Turkish language effective & \\
\hline İnovative thinking & \\
\hline Perceiving time and chronology & \\
\hline
\end{tabular}

As seen in Table 3 there are 27 skills in Social Studies curriculum and there are three skills in Science curriculum.

There are different components in social studies and science curricula. In the context of technology career, including various engineering fields, standards include links to Science, 
Mathematics, Social Studies, Language, Art and Communication. It also emphasizes problem solving, ethics and leadership (Carr, Bennet \& Strobel, 2012).

The integrated structure that will emerge when all the related knowledge and skill achievements of all these programs are connected will also prepare the environment for the implementation of the S-STEM. Hartzler (2000), who examined 30 quantitative studies on the effects of integrated teaching with meta-analysis, reached the following conclusions:

- Students have higher success in interdisciplinary studies

- Compared to traditional classes, success is higher in classes where integrated programs are implemented

- It is an alternative to traditional subject-centered programs without fear of standard test scores

- Integrated program implementations are more successful, especially in four subject areas (Science, Mathematics, Social Studies and Arts).

Given these benefits of integrated teaching, it becomes evident that different disciplines need to be brought together. STEM integration refers to technology/engineering design-based learning approaches that systematically combine science and mathematics education concepts and practices with technology and engineering concepts and practices. STEM integration can be improved by integrating other subjects such as language education, Social Studies, Arts (Sanders \& Wells, 2006). When the researches about STEM are examined, it is observed that there are many researches that take the views of both students and teachers and which are practical, while researches about S-STEM are very few. When especially the literature in Turkey is examined, no research in the S-STEM was found. It is thought that getting the views of teachers who have made practical studies on STEM about S-STEM will shed light on both policymakers and researchers. In line with this requirement, the aim of the research is to get the views of the class teachers about S-STEM.

\section{Method}

\subsection{Research model}

This research is a phenomenological study within the scope of basic qualitative research method. Phenomenological research focuses on how people perceive, recall, and make sense of phenomena, as well as how they talk to others about this phenomenon. It would be important to understand these common experiences in order to develop practices or policies. (Creswell, 2007). In this context, obtaining qualitative data in research requires in-depth interviews with people who experience the phenomenon directly, unlike people who experience it indirectly (Patton, 2014; Sart, 2015). Within the scope of this research, interviews were made with teachers who were trained on STEM, which became a phenomenon in Turkey and in the whole world in the recent years, and who had opportunities to experience STEM in the learning environment.

\subsection{Participants}

Intensity sampling, which is one of the purposeful sampling types, was used in the selection of the participants of this research. Intensity sampling is "information-rich cases that manifest the phenomenon intensely but not extremely" (Miles \& Huberman, 1994). This sampling includes an information-loaded status that shows the phenomenon of interest in an intense way. 
T. Selanik Ay \& N. Duban - According to Primary School Teachers’ Views S-STEM ...

Thus, people with extensive experience or views on the subject of research are selected in the study group (Schreiber \& Asner-Self, 2011; Patton, 2014).

Participants of the research are primary school teachers who have theoretical knowledge of STEM implementations and who have experienced STEM implementations directly and intensely in their classrooms. In addition, the participants graduated from the master's program with thesis in classroom teaching. It is thought that having theoretical knowledge and experience about STEM can increase the participants' interpretation power about the integration of extra disciplines (such as art, entrepreneurship, Social Studies) to STEM. In this context, the viewpoints of the participants about S-STEM, which arise with the integration of Social Studies into STEM, are considered to be important. The fact that the participants of the research are primary school teachers and they teach three of the S-STEM disciplines (Science, mathematics, Social Studies) themselves will increase the effectiveness of their interpretation about this phenomenon.

Of the eight participants in this study, four were female and three were male. Demographic information regarding the gender, professional experience and region of work of the participants are presented in Table 4 . The names of the participants are given in the form of code names.

Table 4. Demographic information of the participants

\begin{tabular}{|c|c|c|c|}
\hline Participants & Gender & Seniority (years) & Region \\
\hline Şerife & Female & 17 & Center \\
\hline Fatma & Female & 4 & District \\
\hline İlknur & Female & 3 & District \\
\hline Hatice & Female & 3 & District \\
\hline Ümit & Male & 9 & District \\
\hline Koray & Male & 11 & Center \\
\hline Yusuf & Male & 15 & Center \\
\hline Sezgin & Male & 13 & Center \\
\hline
\end{tabular}

\subsection{Researchers of the study}

In phenomenological studies, first personal experiences with the phenomenon are described under study. The researcher begins with a full description of his or her own experience of the phenomenon. This is an attempt to set aside the researcher's personal experiences so that the focus can be directed to the participants in the study (Creswell, 2007).

The researchers who conducted this study have a doctorate degree and conducted their doctoral theses in the form of action research. Also, most of their research has different types of qualitative research methods (narrative research, phenomenological research, different data collection techniques; focus group interviews, observations, document review). One of these researchers has a specialization in Social Studies education and the other in science education. In addition, the researchers had two years of experience as researchers of an E-STEM project. However, the researchers have international articles on STEM and STEAM and there are master's theses completed under their consultancy. In this context, it is evident that the researchers are 
competent to conduct this study in the form of a phenomenological research on S-STEM, which occurs with the integration of social information into STEM.

\subsection{Data collection}

Telephone interviews were used in the interview technique used in this phenomenological study. One of the types of interviews made with the participants in the research is phone calls. These interviews have a wide range from open ended interviews to structured interviews (Creswell, 2007). During this research, telephone calls were preferred for data collection. While the telephone offers a useful substitute to face-to-face interviews, researchers should justify why they have chosen this mode of interviewing (Glogowska et al., 2011). The reason for preferring phone calls in this study is that the participants are teaching in different cities.

In this study, forms prepared to be used in a semi-structured interview were used during telephone calls. In qualitative researches internal validity or credibility, expert review or expert revision is one of the strategies used. Surely a good expert review should cover the examination of the raw data reviewed by another expert and should contain how reasonable and logical the findings are (Merriam, 2013). The interview form was developed by researchers then given to three experts to provide internal validity of the interview form, and the form took its final shape by being reviewed. After a student engaged in the pilot interview the sound recording was transcribed. The interview printout form was computerized in order to determine whether or not the questions were clear and comprehensible and the answers of the student reflected the answers of the questions. At the end of this study, the validity of the questions was determined.

In qualitative researches, reliability refers to the stability of multiple encoders' responses to the data set. Regarding the reliability, it is possible to use the inter-encoder consensus based on the use of multiple encoders to analyze the transcribed data (Creswell, 2015). Interview coding keys and interview transcripts were read separately by the researcher and an expert, and the necessary arrangements were made to the topics with an "agreement" and "disagreement". For the reliability calculation of the study, the reliability formula proposed by Miles and Huberman (1994) was used. As a result, the reliability of the research was calculated at 90\%. The fact that reliability calculations exceeded $70 \%$ is considered reliable for research (Miles \& Huberman, 1994). The result obtained here is considered reliable for research.

\subsection{Data analysis}

The data obtained in the research were evaluated by qualitative data analysis. This type of data analysis includes coding the data, separating the text into smaller units (expression, sentence, or paragraph), assigning labels to each one, and grouping the codes into themes. The code label can be derived from the words of the participants, from the explanations created by the researcher, or from concepts used in Social Studies (Creswell \& Plano Clark, 2014). In the research, in the context of induction analysis, the interview transcripts were given a page and line number, then in the sentences mentioned in the transcripts, descriptive index, researcher comment sections were opened next to the explanations within the scope of the S-STEM and these sections were filled together by the researchers. After applying the same process in all transcripts, the process of coding data was started, the relevant codes were collected under the code heading, themes were created and codes related to themes were brought together and findings were presented under the relevant themes. Moreover, the findings obtained as a result of the research for the transferability of the work have also been directly supported by the quotations. 


\section{Results}

In this part of the research, the findings obtained in the context of the primary school teachers' views as follows in Table 5 .

Table 5. The themes obtained from primary school teachers' views on S-STEM

\begin{tabular}{|l|}
\hline Primary school teachers' views on the definition of STEM \\
\hline STEM implementations which performed by primary school teachers \\
\hline Primary school teachers' views on the dimensions which integrate to STEM \\
\hline Primary school teachers' views and suggestions on integrating social studies to STEM \\
\hline Primary school teachers' views on values which handled with STEM \\
\hline Primary school teachers' views on skills which handled with STEM \\
\hline Primary school teachers' suggestions for effective S-STEM implementations \\
\hline
\end{tabular}

As seen at Table 1 there are seven themes about S-STEM. Primary school teachers' views on the definition of STEM are at Table 6.

Table 6. Primary school teachers' views on the definition of STEM

\begin{tabular}{|l|}
\hline Science, technology, engineering and mathematics \\
\hline Multidisciplinary implementations \\
\hline Association between courses \\
\hline
\end{tabular}

When the views of the primary school teachers in the context of the definition of STEM are examined, it is seen that the multidisciplinary structure and interdisciplinary association of the understanding of the disciplines that make up the STEM are included and the definitions of the primary school teachers are superficial.

Regarding the definition of STEM, the Doğa teacher said:

"I think of the merging of many branches of science. The combination of the fields of science, mathematics, engineering and technology."

Regarding the definition of STEM, Illknur teacher used the expressions as:

"I think of the combination of interdisciplinary fields such as engineering and mathematics. I can say that this is an understanding that has been put forward with the unification of these disciplines."

Yusuf teacher's view on the definition of STEM is:

"An implementation in which the fields of science, mathematics and technology are implemented in an integrated manner, aiming to attract the attention of the student and also having different latent goals."

Table 7. STEM implementations of primary school teachers in their classes

\begin{tabular}{|l|}
\hline Car design \\
\hline Catapult \\
\hline Simple Machines \\
\hline Force and Motion \\
\hline Imaginary Amusement Park \\
\hline
\end{tabular}




\begin{tabular}{|l|}
\hline Human and Environment \\
\hline Economical use of resources \\
\hline Push, Pull and change direction \\
\hline Bridge construction \\
\hline Charcoal portrait scaling study (STEAM) \\
\hline Plant growth (supposed to be STEM) \\
\hline
\end{tabular}

Within the scope of STEM implementations carried out by the primary school teachers, it was revealed that simple machines and force and motion issues were included, and within the scope of STEM implementations, the protection of the natural environment, car, catapult, amusement park and bridge construction was used, and the scaling study of a portrait was made as a STEAM study. It can be thought that, since mechanical implementations provide ease in creating concrete examples, the subjects of force and motion and simple machines are more frequently used by teachers. Since there is not much theoretical detail in science subjects especially at primary school level, it can be considered natural that the implementation examples are simpler. The fact that simple activities related to pushing, pulling and changing direction are made within the scope of force and movement, and the study about plant growth is a simple science experiment shows that these implementations, which are considered as STEM, do not actually go beyond the basic science activities.

Şerife teacher, who carried out STEM practice in the activity for protection of the natural environment within the scope of the human and environmental unit, explained her work as follows:

"We had an activity on the environment before as STEM implementation. It was about environmental protection. We created a natural environmental area here. First, the children made mathematical calculations on an area we found, on it, they determined parks, natural environment, artificial environment activities and made everything on it. The children built a factory using the engineering field. Then, we talked about what can be done with fields such as environmental engineering and construction engineering. Here, using technology, we had an event on the benefits and harms of factories and technology."

The fact that the details about the integration of disciplines could not be included in the example of STEM study on the economical use of resources, which is a common subject in science and Social Studies courses, suggests that teachers still cannot clarify this issue in their minds. Fatma teacher's comment on this subject is as follows:

"A STEM study can be conducted on the economical use of resources. Because if a product is going to come out, I think there is a social problem, and I think that the students can develop a product about saving resources."

Sezgin teacher explained the construction of the car by using the process effectively at primary school level and integrating the disciplines within the scope of STEM implementation with the following words:

"There can be nice activities related to STEM, and even very cost-effective and sample implementations that students will enjoy can be done. We did something like this: I applied this to the teachers at the time of the seminar and also to the students during the year. We designed a car using pet bottles, four caps, skewers, balloons. We designed a car with these materials and the kids liked it a lot. The 
teachers I worked with (group) also liked it very much, they likewise made similar STEM practices. Then the students raced the cars."

Koray teacher, who was asked to explain a STEM implementation in his classroom, described the implementation he carried out as follows:

"There was a subject in the science as "Let's observe the growth of a plant". There were visuals in the books, they explained the process, but I also wanted to ensure that students observe the effect of sunlight on the plant. We created an environment in the lab. The study took about two weeks. We have one dark room inside the lab. A group of students grew a plant there. Another group grew a plant in front of the glass that received the sun's rays. We were growing beans in cotton. One of our groups raised and observed their beans in an area that saw the sun but we made a shadow area by placing obstacles. Each group had a paper in front of them and they made notes. They wrote the date, wrote down the changes they observed in plants. We definitely measured the height of the plants once a day. We especially left one bean without water and we saw what happened when it was dehydrated. The plant that did not receive sunlight grew white. Children were also very surprised by this. Considering the feedback I received, the students wanted to experiment again, it was a good work."

As seen above, the example given by Koray teacher in the context of STEM implementation is a simple science experiment. It does not cover most of STEM's dimensions. In this context, it would not be wrong to say that teachers have a superficial and sometimes wrong view towards STEM.

Table 8. Primary school teachers' views on dimensions that can be integrated into STEM

\begin{tabular}{|l|l|}
\hline \multirow{5}{*}{ Art } & Art comes into play in STEAM implementations \\
\hline \multirow{5}{*}{ Social Studies } & I heard there was entrepreneurship in E-STEM studies \\
\cline { 2 - 3 } & Risk taking \\
\cline { 2 - 3 } & Innovation \\
\cline { 2 - 3 } & Creativity \\
\hline & Architecturally examining the houses in the vicinity \\
\cline { 2 - 3 } & Environmental pollution \\
\cline { 2 - 3 } & Sociological issues \\
\cline { 2 - 3 } & Natural and human elements \\
\cline { 2 - 3 } & Solution to social problems \\
\cline { 2 - 3 } & Formation of landforms (aquarium arrangement) \\
\hline
\end{tabular}

When the views of the primary school teachers on the dimensions that can be integrated into STEM are examined, it is seen that they talk about STEAM practices that are carried out by including artistic dimension the most. This situation can be explained by the fact that many studies related to STEAM in the literature (Akbaba, 2017; Tüzün and Tüysüz, 2018; Maeda, 2013; Kelly and Guyotte, 2019; Pitikhate, Sakda, Anurak \& Kitdakorn, 2016; Ghanbari, 2015) are found. In addition to art, entrepreneurship and Social Studies are also expressed as dimensions that can be integrated into STEM. E-STEM implementations have been mentioned by emphasizing risk taking, innovation and creativity dimensions regarding entrepreneurship. They 
stated that the discipline of Social Studies can be integrated into STEM with architectural examination of houses in the vicinity, environmental pollution, sociological issues, natural and human elements, solution to social problems, formation of landforms (aquarium arrangement) dimensions.

Şerife teacher, who emphasizes the integration of art to STEM and explains its importance, expressed her views on STEAM with the following words:

"Art can be added, and activities made in terms of artistic perspective and aesthetic concern can turn into STEAM. If I give an example from the field calculations in engineering and mathematics, visual activity is also important for children when doing an activity related to this. At this point, children will appreciate artistic color harmony more. I think STEAM is important for the development of aesthetic sense."

Ümit teacher stated that Social Studies and life science courses can be added to STEM:

"Social Studies can be added to STEM first. Geography is in social sciences. These can take place separately. It depends on the level. Life science course includes It in the primary school level, life sciences can be added in the level of $1^{\text {st }}, 2^{\text {nd }}$ and $3^{\text {rd }}$ grades."

Yusuf teacher, who emphasized that a needs analysis should be made in order to understand which disciplines have more deficiency to decide which discipline to be integrated in STEM, said he thought Social Studies were neglected in this context, stated that Social Studies can be integrated into STEM and explained an activity he carried out in his classroom as follows:

"To integrate a discipline to STEM, it should be decided which discipline needs it. For example, Social Studies are highly neglected, this can be integrated. We talked about this with our Social Studies teachers and thought if Social Studies could be integrated into STEM. We thought about such a thing: we could do something based on the social problems. We made this implementation to our students. We have kinex sets we use in the institution. There are type projects in these sets. For example, you build a tower, helicopter, car. These were all close ended. After making all of them, we wanted to make something else. We told the students about buses bought for Afyon recently. In these buses, the wheelchair ramp is manual. The driver gets off the bus in the station, goes to the rear door, opens the ramp, lets the citizen in and then he closes the ramp again manually. Students noticed this. They designed a system using kinex sets for the solution of this. STEM should be used for Social Studies. They should be allowed to solve daily problems."

Hatice teacher, who includes entrepreneurship as a dimension that can be integrated into the S-STEM, explained her view as follows:

"I thought this for active citizenship unit. We can think it as producing a product and selling it. This sale can take place in the school for parents or other students. At the point of marketing, entrepreneurship is included in the study. Persuading, calculating cost, profit or loss can be included."

The views and suggestions of the primary school teachers about integrating the Social Studies course into STEM are given in Table 9.

As it can be seen in Table 9, primary school teachers have four of the eight learning areas in the Social Studies curriculum (People, Places and Environments, Culture and Heritage, Production, Distribution, Consumption, Science, Technology and society) in their views regarding the subjects that can be included in the Social Studies in the context of S-STEM. The dimensions they associate these learning areas with STEM are listed as architectural structure, organic agriculture production, environmental pollution, solution of disability problems, and cultural values. For example, Fatma teacher expressed her examples from two learning areas with the following words: 
"We can directly relate production distribution consumption contact to economic use of resources. There was also an achievement in the subject of science, technology and society: The student develops a design and an idea for the needs based on his/her own needs. I think they can put forward products in accordance with their own needs."

Table 9. Views and suggestions of primary school teachers about Integrating Social Studies Course to STEM

\begin{tabular}{|l|l|}
\hline \multirow{2}{*}{ People, Places and Environments } & Working on maps \\
\cline { 2 - 2 } & $\begin{array}{l}\text { Evaluating the houses in the immediate vicinity in artistic and } \\
\text { architectural terms }\end{array}$ \\
\cline { 2 - 2 } & To conduct studies within the scope of natural and human elements \\
\hline Culture and Heritage & Cultural elements of people who lived in the past \\
\hline $\begin{array}{l}\text { Production, Distribution, } \\
\text { Consumption }\end{array}$ & Organic Production \\
\hline Science, Technology and Society & $\begin{array}{l}\text { Producing solutions for the solution of environmental pollution } \\
\text { problem }\end{array}$ \\
\hline Solution to social problems & Making wheelchair ramps for buses \\
\hline
\end{tabular}

Şerife teacher stated that S-STEM implementations can be made with the integration of different learning areas into STEM within the scope of Social Studies course with these words:

"Subjects related to science, technology and society can be added to STEM or building a factory related to the subjects of production distribution consumption and its phases are related to many areas of professions such as engineering. Collecting prices for these is related to math and trees are related in the part of distribution. Markets are related to technology. As I said, production, distribution and consumption unit is integrated to science, technology and society in many aspects. The unit of people, places and environments can also be added. We made an activity on environment. We can make integration in the protection of environment, natural environment and artificial environment."

The view of Koray teacher, who thinks the subject of natural and human elements included in the learning area of people, places and environments can be integrated into STEM implementations, is as follows:

"I think that the formation of earth shapes, natural and human elements can be processed with STEM. These are formations, emerging mountains, seas, etc. I think these can be handled using STEM."

Sezgin teacher stated that Social Studies can be carefully integrated into STEM regardless of learning area or unit:

"The STEM wheel (can be thought of as a pulley system) is mentioned. The important thing when describing STEM is how the fields are connected to each other. There is a STEM load at the bottom. The important thing is that the wheels are lifting that STEM load. But it is very important to connect the wheels. The point to be considered here is to connect the achievements of the Social Studies course with the other achievements. In other words, it is important to integrate Social Studies, science and mathematics appropriately and lift the load in a balanced way. Attention should be paid to this." 
In addition, teachers expressed views about the association of the solution of social problems and STEM practices in the context of Social Studies as a reflective study area from three basic concepts in Social Studies teaching. In the Social Studies curriculum, there are dimensions such as learning areas, key competencies, achievements, values and skills. Hatice teacher, who discusses obesity and unhealthy nutrition in the field of learning "production, distribution and consumption," said:

"In the learning field of production, distribution, and consumption, it is possible to design projects for growing organic products by researching what is grown in which region."

In Table 8, the views of the primary school teachers about the values that can be handled in S-STEM implementations are given as follows.

Table 10. Views of the primary school teachers about the values that can be handled in S-STEM implementations

\begin{tabular}{|l|}
\hline Responsibility \\
\hline Sensitivity \\
\hline Being Scientific \\
\hline Solidarity \\
\hline Mutualization \\
\hline Respect \\
\hline Economy \\
\hline
\end{tabular}

As seen in Table 10, when the views of the class teachers about the values that can be handled in S-STEM implementations are examined, it is seen that they talk about responsibility, sensitivity, being scientific, solidarity, mutualism, respect and economy values. There are many studies (Ylldırım, 2018; Morrison, 2016) that emphasize the importance of group work in STEM implementations. Many values such as solidarity, mutualism and responsibility can be expressed as values that can be gained to students through group work. Since S-STEM implementations are also carried out in the form of group works, values such as economy, sensitivity, and being scientific can be gained through discussions on many issues and creative practices for finding solutions. The views of primary school teachers about the skills that can be handled in S-STEM implementations are given in Table 6 as follows.

Yusuf teacher exemplified how the economy value emerged in his STEM implementation as follows:

"When I made the students talk about economy, they said they could design a robotic arm. It would close the window when it remained open, it would measure the amount of oxygen outside and open the door when the indoor oxygen amount decreased with a voice."

Stating that many values are already spontaneously included in the process within the scope of the S-STEM, Koray teacher emphasized the group works and expressed his view as follows:

"Since S-STEM implementations are conducted with small groups of students, cooperating, respecting, taking responsibility, mutualization, solidarity, 
T. Selanik Ay \& N. Duban - According to Primary School Teachers’ Views S-STEM ...

emphasizing being scientific by accessing the information in the first hand by making research are spontaneously included in the process."

Table 11. Primary school teacher' views on skills that can be addressed in S-STEM implementations

\begin{tabular}{|l|}
\hline Environmental literacy \\
\hline Digital literacy \\
\hline Media literacy \\
\hline Observation \\
\hline Research \\
\hline Communication \\
\hline Entrepreneurship \\
\hline Critical thinking \\
\hline Decision making \\
\hline
\end{tabular}

As can be seen in Table 11, primary school teachers stated that 9 out of 27 skills included in the Social Studies curriculum can be gained to students through S-STEM implementations. They expressed these skills in the form of environmental literacy, digital literacy, media literacy, observation, research, communication, entrepreneurship, critical thinking and decision making. Considering that research and high-level thinking skills are inherent in STEM, it is thought that it is possible to provide these skills expressed by primary school teachers with S-STEM.

Ümit teacher made the following explanation about media literacy and digital literacy in the context of skills that can be gained with S-STEM implementations:

"In technology use, how a person should use technology or how media literacy should be for television, how safe internet should be, I think these are included in the Social Studies. We can integrate these for students in the Social Studies. We can integrate stem in Social Studies in this way, like safe use of internet. Other than that, if there is a work on a map regarding STEM and if the activity is to be carried out on this map and a technological product about maps is to be designed, the map part of Social Studies can be integrated."

Hatice teacher's point of view, which emphasizes environmental literacy skills within the scope of the S-STEM, is as follows:

"In achievements as the student uses technological products without harming himself/herself and environment' in the learning area of science, technology and society, developing environmental friendly products can be emphasized or the process can be conducted by real life problems based on gaining environmental literacy directly."

The view of the Koray teacher, who emphasizes research skills within the scope of the S-STEM, is as follows:

"While students try to solve knowledge-based life problems in their S-STEM studies, they will determine the point they will act by using the data they have obtained by 
making researches from different sources and using their decision making skills.

Therefore, both research and decision making skills will be involved."

The views of primary school teachers regarding the possible difficulties in Social Studies integration to STEM are given in Table 12 as follows.

Table 12. The views of primary school teachers regarding the possible difficulties in Social Studies integration to STEM

\begin{tabular}{|l|}
\hline Integration of the Numerical-Verbal course may be challenging. \\
\hline Science-Social complexity may be experienced \\
\hline Brings excess workload \\
\hline $\begin{array}{l}\text { The teaching of different teachers in these courses at the secondary level can be challenging in } \\
\text { terms of cooperation }\end{array}$ \\
\hline Preparing S-STEM plans can be challenging \\
\hline Determining the gains that can be associated with each other can be challenging \\
\hline $\begin{array}{l}\text { I do not think that there will be a problem because the subjects that can be associated with each } \\
\text { other at the elementary school level can be handled by the classroom teacher on the same date. }\end{array}$ \\
\hline STEM helps to embody Social Studies issues that appear more abstract than science \\
\hline Problems may arise because teachers are closed to learning and innovation \\
\hline Using technical materials (tools) in technology and engineering dimensions can be a problem \\
\hline
\end{tabular}

When the views of the primary school teachers regarding the difficulties in Social Studies integration to STEM are examined, the difficulties of numerical and verbal course integration, the increase in workload, the difficulties in determining the gains, and the deficiencies that may be experienced in the cooperation between the branch teachers in the second level are expressed. On the other hand, it is also stated that the teaching by primary school teachers in all courses will facilitate integration at primary school level and STEM will contribute in the context of embodying abstract topics in Social Studies course. It is thought that the lack of any research in Turkey related to the S-STEM implementation for primary school teachers and the fact that teachers and prospective teachers did not receive any training through pre-service or in-service training caused some dimensions to be perceived as a problem. It is hoped that as the experience of primary school teachers on STEM increases, they will be more open about the solution of the problems encountered and the integration of new areas.

In the context of possible problems, Şerife teacher stated that the integration of numerical-verbal courses can confuse teachers and cause them to stay away from the subject:

"The courses are divided as numerical and verbal, thus the teachers may think these two cannot be integrated and they may not want to act together. Primary school students do not think this discrimination much but older students may think themselves as more competent in one of verbal and numerical areas and if they think they are good at verbal courses they may not be open to science or math courses."

Ümit teacher, who thinks that the teachers have problems in preparing course plans for STEM and that similar problems may be experienced in the S-STEM plans in parallel with this, explained a possible problem as follows: 
"I think the biggest problem for teachers is to create the course plan. As there is not a defined frame for this, teachers have difficulties. Many difficulties are experienced in determining where to start, how to put forward etc. As I can see regarding the training given, everybody has a course plan of their own. There is no defined frame. Therefore, I think teachers are confused. Everybody starts from a different point of the subject. And there is no certain frame about STEM in writing the course plans and the same uncertainty will be experienced in S-STEM. There is no defined frame. Therefore, the teachers have difficulties in preparing these. Which one will be followed? To which side will we look? Or how can I prepare it if I am to prepare? Does the course plan I prepare comply with STEM? Will it be relevant to STEM? There is always a difficulty about these questions."

Table 13. Primary school teachers' suggestions for efficient S-STEM implementations

Number of studies on STEM and S-STEM can be increased

School administration and parents can be persuaded for the contributions of S-STEM

STEM and S-STEM dimensions can be taught in graduate education.

Studies such as STEM and S-STEM can be reported to the upper level practices can be encouraged

Platforms where STEM and S-STEM implementations are shared can be created

Institutions can prepare action plans (program, sample activity booklet)

Applied in-service trainings can be given by expert staff in STEM and S-STEM dimensions

STEM and S-STEM dimensions can be included in the pre-service level in teacher education

Sample courses can be prepared by academicians and S-STEM implementation videos can be shared on platforms which developed for S-STEM

Workshops can be organized on the preparation of STEM and S-STEM plan

As can be seen in Table 13, primary school teachers stated increasing the number of SSTEM and STEM researches, persuading administrators and parents for S-STEM and STEM, sharing sample practices and course plans by institutions, academicians and teachers via various platforms, including trainings in the pattern of workshops in pre-service and in-service training as suggestions for effective S-STEM implementations. In this context, it is seen that primary school teachers include suggestions in both implementation and research dimensions, and especially emphasize the databases where the implementation examples will be shared.

Fatma teacher explained her view that the students can be guided with sample practices in these words:

"I think teachers have the most difficulty in the system in practice. We can understand the theory but practice can be difficult. This can be their concern. I think sample practices can be made and teachers can adapt other achievements themselves."

Among the participants who thought that in-service training should be applied on STEM and S-STEM subjects, Ümit teacher expressed his expectation regarding the content of the training with the following words:

"First, teachers should get STEM training in teacher training. This STEM training should be applied, it should not remain only in theory. The duration must be long. 
I think one week is not enough for STEM training. Implementations may be made in a time frame of one month in groups in certain time periods."

\section{Conclusion and discussion}

When the views of the primary school teachers in the context of "definition of STEM" are examined, it is seen that the disciplines that make up the STEM, the multidisciplinary structure of the understanding and interdisciplinary association are included, and the definitions of the class teachers are superficial. Wang, Moore, Roehrig and Park (2011) stated in the literature that the two words frequently used to describe STEM are multidisciplinary and disciplinary and emphasized that most of the research focuses on how to integrate STEM disciplines and the degree of integration. In this context, the research results are compatible with each other.

Within the scope of STEM implementations carried out by class teachers, it was revealed that simple machines and force and motion issues were included, and within the scope of STEM implementations, the protection of the natural environment, car, catapult, amusement park and bridge construction were made, and the scale study of a portrait was carried out as a STEAM study. In the research conducted by Timur and Inançlı (2018), it was observed that similarly, catapult, bridge, and car construction were mentioned. In this context, it was determined that teachers' STEM practices are parallel.

Class teachers included four of the eight learning areas (People, Places and Environments, Culture and Heritage, Production, Distribution, Consumption, Science, Technology and Society) in their views on the subjects that can be addressed in the Social Studies course in the context of the S-STEM. In addition, they stated that Social Studies can be integrated into STEM in the context of the solution of social problems. They emphasized that the dimensions of examining the houses in the vicinity in architectural terms, environmental pollution, sociological issues, natural and human elements, solution to social problems, formation of landforms (aquarium arrangement) dimensions that are included in the Social Studies course can be easily integrated into STEM. Dare Ellis and Roehrig (2018) stated integration as deepening students' understanding of STEM disciplines, handling student understanding within socially and culturally relevant STEM contexts, and increasing interest in STEM disciplines as well as the integration of STEM disciplines. In this context, it can be said that the results obtained in the context of the relationship between the solution of social problems and integration are compatible.

When the views of the primary school teachers about the values that can be addressed in S-STEM implementations are examined, it is seen that they talk about responsibility, sensitivity, being scientific, solidarity, mutualism, respect and economy values. There are many studies (Yıldırım, 2018; Morrison, 2016) that emphasize the importance of group work in STEM implementations. Many values such as mutualism, solidarity and responsibility can be expressed as values that can be gained to students through group work. Since S-STEM implementations are also carried out in the form of group works, values such as economy, sensitivity, and being scientific can be gained through discussions on many issues and creative practices for finding solutions. Sejati, Firman and Kaniawati (2017) used observation tables about students' responsibility profile from the beginning to the end of their practices with STEM and categorized their responsibility value in four different dimensions. Observation evaluation lists include students' responsibilities in the context of self-control, with evidence that they do not harm others verbally or physically and work well with others. While group responsibilities such as settling conflicts of interest in an amicable way and making effort are emphasized, articles are included in the context that each student individually tried to achieve the given task, focused on development, worked both individually and with group, remained in task without direct instruction or monitoring while making decisions, directed himself/herself, did not follow bad examples around or peer pressure. As a result of the observations made, it was determined that there was an increase 
in the observations regarding the responsibility values every implementation day until the end of the implementation.

When the views of the primary school teachers regarding the difficulties in Social Studies integration to STEM are examined, the difficulties in numerical and verbal course integration, the increase in workload, the difficulties in determining the achievements, and the difficulties that may be experienced in the cooperation between the branch teachers in the secondary level are expressed. On the other hand, it is also stated that the teaching by primary school teachers in all courses will facilitate integration at primary school level and STEM will contribute in the context of embodying abstract topics in Social Studies course. Dare, Ellis and Roehrig (2018) stated the three important factors affecting successful STEM integration as curriculum materials deficiencies and inability to associate goals in integration, insufficiency in students' STEM experiences, teachers' integrated STEM assessment needs (Brophy et al., 2008; Guzey, Moore, Harwell \& Moreno, 2016; Moore et al., 2014; NRC, 2012; Roehrig et al., 2012; Wang, Moore, Roehrig, Gillian \& Park, 2011).

It was seen that primary school teachers suggested increasing the number of S-STEM and STEM researches, persuading administrators and parents for S-STEM and STEM, sharing sample practices and course plans by institutions, academicians and teachers via various platforms, including trainings in the pattern of workshops in pre-service and in-service training for effective S-STEM implementations. In this context, it was seen that primary school teachers included suggestions in both implementation and research dimensions, and especially emphasized the databases where the implementation examples will be shared. In their research Çınar, Pırasa, Uzun and Erenler (2016) determined that before receiving STEM training preservice teachers emphasized they would integrate science only with mathematics in their classrooms. However, after the STEM training, they gained an interdisciplinary point of view that they could integrate science, mathematics, engineering and technology in their classrooms and in addition, nearly all pre-service teachers stated that this integration was required for the individual and social development and education for the students. In this research, the dimension of qualifying teachers through teacher training and pre-service training on the S-STEM expressed by teachers is compatible with the results obtained with the research.

In the light of the results obtained, the following recommendations can be included:

- Theoretical and practical training can be given to teachers and prospective teachers to increase their S-STEM awareness through preservice and in-service training.

- In order to eliminate the lack of literature in Turkey on S-STEM, different types of research, such as qualitative, quantitative, action research, can be carried out.

- Various seminars to inform school administrators and families about SSTEM can be carried out in cooperation with the Ministry of Education and Universities.

- In the second stage, common laboratory implementations can be made in the context of increasing interdisciplinary cooperation for S-STEM implementations and information can be provided on designing common activity plans. 
Acknowledgements

This research did not receive any specific grant from funding agencies in the public commercial, or not-for-profit sectors.

The authors declare no competing interests.

\section{References}

Adams, A. E., Miller, B. G., Saul, M., \& Pegg, J. (2014). Supporting elementary pre-service teachers to teach stem through place-based teaching and learning experiences. Electronic Journal of Science Education, 18(5), 1-22.

Brophy, S., Klein, S., Portsmore, M., \& Rogers, C. (2008). Advancing engineering education in P12 classroom. Journal of Engineering Education, 97(3), 369-387.

Bybee, R. W. (2010). Advancing STEM education: A 2020 vision. Technology and Engineering Teacher, $70(1)$, 30-35.

Carol, K., \& Scott, C. (2017). Creating STEM kits for the classroom. Retrieved from http://digital.nsta.org/publication/?i=429899\&article id=2849756\&view=articleBr owser\&ver=html5\#\{"issue id":429899,"view":"articleBrowser","publication id":"13 899","article id":"2849756"\}.

Carr, R. L., Bennett, L. D., \& Strobel, J. (2012). Engineering in the K-12 stem standards of the 50 U.S. states: An analysis of presence and extent. Journal of Engineering Education, 101(3), 539-564.

Chute, E. (2009). STEM education is branching out: Focus shifts from making science, math accessible to more than just brightest. Pittsburg Post-Gazette. Web: http://www.postgazette.com/news/education/2009/02/10/STEMeducation-isbranchingout/stories/200902100165adresinden16.02.2017tarihindeerișilmiștir.

Creswell, J. W. (2007). Qualitative inquiry \& research design, choosing among five approaches. Second Ed. USA: Sage publications.

Creswell, J. W., \& Plano Clark, V. L. (2014). Designing and conducting mixed methods research. (Yüksel Dede, Selçuk Beşir Demir \& A. Delice, Translation Ed.). Ankara, Türkiye: Anı Yayıncılı.

Creswell, J. W. (2015). Mixed research methods-qualitative and quantitative research design according five approaches. (M. Bütün \& S. B. Demir, Translation Ed.). Ankara: Siyasal Publishing.

Çınar, S., Pırasa, N., Uzun, N., \& Erenler, S. (2016). The effect of stem education on pre-service science teachers' perception of interdisciplinary education. Journal of Turkish Science Education, 13, 118-142.

Dare, E. A., Ellis, J. A., \& Roehrig, H. (2018). Understanding science teachers' implementations of integrated STEM curricular units through a phenomenological multiple case study. International Journal of STEM Education, 5(4), 1-19. 
Garibay, J. C. (2015). Stem students' social agency and views on working for social change: Are stem disciplines developing socially and civically responsible students? Journal of Research in Science Teaching, 52(5), 610-632.

Ghanbari, S. (2015). Learning across disciplines: A collective case study of two university programs that integrate the arts with STEM. International Journal of Education \& the Arts, 16(7). Retrieved from http://www.ijea.org/v16n7/.

Glogowska, M., Young, P., \& Lockyer, L. (2011). Propriety, process and purpose: Considerations of the use of the telephone interview methods in an educational research study. Higher Education, 62, 17-26.

Guzey, S. S., Moore, T. J., Harwell, M., \& Moreno, M. (2016). STEM Integration in middle school life science: Student learning and attitudes. Journal of Science Education and Technology, 25(4), 550-560. https://doi.org/10.1007/s10956-016-9612-x

Hartzler, D. S. (2000). A meta-analysis of studies conducted on integrated curriculum programs and their effects on student achievement (Doctoral dissertation). Indiana University.

Langdon, D., McKittrick, G., Beede, D., Khan, B., \& Doms, M. (2011). STEM: Good Jobs Now and For The Future, Retrieved from http://www.esa.doc.gov/sites/default/files/stemfinalyjuly14 1.pdf.

Maeda, John (2013). STEM + Art = STEAM, The STEAM Journal, 1(1), https://doi.org/10.5642/steam.201301.34

Maguth, B. (2012). In defense of the social studies: Social studies programs in STEM education. Social Studies Research and Practice, 7(2), 84.

Merriam, S. B. (2013). Qualitative research: A guide to design and implementation (S. Turan, Translation Ed.). Ankara: Nobel Publishing.

Miles, M. B., \& Huberman, A. M. (1994). Qualitative data analysis: An expanded sourcebook. (2nd Edition). Calif.: SAGE Publications.

Morrison, J. (2006). TIES STEM education monograph series, attributes of STEM education. Baltimore, MD: TIES.

Kelly, W. G. (2019). Toward a philosophy of STEAM in the Anthropocene. Educational Philosophy and Theory, $\mathrm{o}(\mathrm{o}), 1-11$.

National Research Council (2011). Reference manual on scientific evidence: Third Edition. Washington, DC: The National Academies Press.

Manfra, M. M. (2013). Social education. National Council for the Social Studies, 77(2), 95-98.

Meyrick, K. M. (2011). How stem education improves student learning. Meridian K-12 School Computer Technologies Journal, 14(1), 1-5.

Patton, M. Q. (2014). Qualitative research and evaluation methods, $1^{\text {st }}$ Ed. (M. Bütün \& S. B. Demir, Translation Ed.). Ankara: Pegem Publishing. 
Pitikhate,S., Sakda, S., Anurak, J., \& Kitdakorn, K. (2016). Tree robot: An innovation for STEAM education. Real-time Computing and Robotics (RCAR) IEEE International Conference (pp. 338-341).

Pryor, C. R., \& Kang, R. (2013). Project-based learning: An interdisciplinary approach for integrating social studies with STEM. In R. M. Capraro, M. M. Capraro \& J. Morgan (Eds.), STEM Project-based learning: An integrated Science, Technology, Engineering, and Mathematics (STEM) Approach (pp. 129-138).

Roehrig, G. H., Moore J., T., Wang, H.-H., \& Park, M. S. (2012). Is adding the E enough? Investigating the impact of K-12 engineering standards on the implementation of STEM integration. School Science and Mathematics, 112(1), 31-44.

Sanders, M., \& Wells, J. G. (2006). Integrative STEM education. Retrieved from http://www.soe.vt.edu/istemed/.

Sanders, M. (2009). Stem, stem education, stemmania. The Technology Teacher, 68(4), 20-26.

Sart, G. (2015). Fenomenoloji ve yorumlayici fenomenolojik analiz. In F. N. Seggie \& Y. Bayyurt (Eds.), Nitel araştirma yöntem, teknik, analiz ve yaklaşimlari, ani yayincilik, pp. 7082.

Schreiber, J. B., \& Asner-Self, K. (2011). Educational research. The interrelationship of questions, sampling, design, and analysis. NJ: John Wiley \& Sons, Inc.

Social Studies: The Original STEM (NCSS Report) (2017). Retrieved from https://www.socialstudies.org/getting-social/social-studies-original-stem.

Thomasian, J., \& National Governors Association, C. P. (2011). Building a science, technology, engineering, and math education agenda: An update of state actions. Retrieved 10 June 2018, from https://files.eric.ed.gov/fulltext/ED532528.pdf.

Wagner, T. (2008). Even our "best" schools are failing to prepare students for $21^{\text {st }}$ century careers and citizenship. Retrieved 20 December 2018, from http://vanschools.org/UserFolders/CurriculumandInstruction/rigor redefinedo 53 2012.pdf.

Wang, H.-H., Moore, T. J., Roehrig, G. H., \& Park, M. S. (2011). STEM integration: Teacher perceptions and practice. Journal of Pre-College Engineering Education Research ( $J$ PEER), 1(2). https://doi.org/10.5703/1288284314636

Wells, J. G. (2008, November). STEM education: The potential of technology education. In $95^{\text {th }}$ Mississippi Valley Technology Teacher Education Conference, St. Louis, MO (Vol. 41).

Yıldırım, B. (2018). STEM Uygulamalarına yönelik öğretmen görüşlerinin incelenmesi. Eğitim Kuram ve Uygulama Araştırmalar Dergisi, 4(1), 42-53. 
T. Selanik Ay \& N. Duban - According to Primary School Teachers' Views S-STEM ...

C O A $\mathrm{s}$ 